\title{
Dual Carriage of Hepatitis B Surface and Hepatitis B Envelope Antigen in Children in a Tertiary Health Facility in the Poorest Region of Nigeria, 2000-2015
}

\section{Isaac Warnow Elon ${ }^{1}$, Jalo Iliya ${ }^{1}$, Alkali Yaya ${ }^{1}$, Ajani Ayomikun ${ }^{2}$, Abubakar Joshua Difa $^{3}$, Oyeniyi C and Danlami Halilu 5}

${ }^{1}$ Department of Paediatrics, Gombe State University, Nigeria

${ }^{2}$ Department of Paediatrics, Federal Teaching Hospital, Gombe, Nigeria

${ }^{3}$ Department of Community Medicine, Gombe State University, Nigeria

${ }^{4}$ Infectious Diseases Training and Research group, Gombe, Nigeria

${ }^{5}$ Department of Medical Microbiology, Federal Teaching Hospital, Gombe, Nigeria

*Corresponding author: Isaac Warnow Elon, Department of Paediatrics, College of Medical Sciences, Gombe State University, Nigeria, Tel: +23480-2378-5735

\begin{abstract}
Introduction: Hepatitis B infection is endemic in sub-Saharan Africa, where transmission predominantly occurs in infants and children by perinatal and horizontal routes. The risk of chronic infection peaks when infection is acquired early.

Materials and methods: Records of Hepatitis B surface and envelope antigen results in Federal Teaching Hospital, Gombe between May 2000 and May 2015 were retrieved and analyzed.

Results: Individuals tested for Hepatitis B surface antigenaemia totaled 22862. Children between 0-18 years were $2,487(10.9 \%)$. Among children tested, males accounted for $1307(52.6 \%)$ and females $1180(47.4 \%)$. Infants contributed $57(2.3 \%), 1-4$ year old children $282(11.3 \%)$; 5-9 year old children 519 (20.9\%) and adolescents 1629 (65.5\%).

HBsAg sero-positivity was $17.7 \%(441 / 2487)$ among children tested. Sero-positivity was (3.5\%), (2/57). $11.3 \%$ (32/282), 17.3\% (90/519) and 19.5\% (317/1629) in infants, children ages 1-4years, 5-9years and adolescents respectively.

$2.6 \%(1 / 38)$ and $5.3 \%(1 / 18)$ of male and female infants respectively were $\mathrm{HBsAg}$ positive. Among children aged 1-4years, $13 \%(23 / 177)$ of males and $8.6 \%(9 / 105$ of females were HBsAg seropositive; $15.3 \%$ (47/307) and $20.3 \%$ $(43 / 212)$ of male and female 5-9 year old children respec tively were HBsAg positive. $14.7 \%$ (124/844) of adolescent females had Hepatitis B surface antigen. Adolescent males
\end{abstract}

demonstrated the highest sero-positivity rate $193 / 785$ $(24.6 \%)$.

$54.6 \%(241 / 441)$ of children who demonstrated Hepatitis B surface antigen were tested for carriage of the Hepatitis B envelope antigen. Males accounted for $152(63.1 \%)$ and females 89 (36.9\%).

$41.1 \%(99 / 241)$ of children tested had $\mathrm{HBe}$ antigen. Of these, males accounted for $69(69.7 \%) .1 / 99(1.0 \%)$ of them were infants; 9 (9.1\%) 1-4years; $21(21.2 \%) 5-9$ years and $68(68.7 \%)$ adolescents.

$50 \%(1 / 2)$ of infants; $44.4 \%(8 / 18)$ children aged $1-4$ years, $43.8 \%(21 / 48)$ of $5-9$ year old children and $39.3 \%(68 / 173)$ adolescents had dual carriage of $\mathrm{HBsAg}$ and $\mathrm{HBeAg}$.

Conclusion: Hepatitis B surface antigen is high among adolescent males. Infants and young children have the highest carriage rate of both surface and envelop antigen. Universal screening for HBV in pregnancy, neonatal HBV vaccinations and immunoglobulin prophylaxis need urgent implementation and strengthening in Nigeria and indeed in Sub-Sahara Africa.

\section{Introduction}

Hepatitis B infection is endemic in sub-Saharan Afri$\mathrm{ca}$, where transmission predominantly occurs in infants and children by perinatal and horizontal routes $[1,2]$. The risk of chronic infection peaks when infection is ac-

Citation: Isaac WE, Iliya J, Yaya A, Ayomikun A, Difa AJ, et al. (2020) Dual Carriage of Hepatitis B Surface and Hepatitis B Envelope Antigen in Children in a Tertiary Health Facility in the Poorest Region of Nigeria, 2000-2015. Int J Virol AIDS 7:060. doi.org/10.23937/2469-567X/1510060 Accepted: April 08, 2020: Published: April 10, 2020

Copyright: (c) 2020 Isaac WE, et al. This is an open-access article distributed under the terms of the Creative Commons Attribution License, which permits unrestricted use, distribution, and reproduction in any medium, provided the original author and source are credited. 
quired early.1 Most of the burden of disease from Hepatitis $B$ Virus infection comes from infections acquired before the age of 5 years. Therefore prevention of HBV infection focuses on children under 5 years of age. The United Nations selected the cumulative incidence of chronic HBV infection at 5 years of age as an indicator of the Sustainable Development Goal target for "combating hepatitis" [1,2].

Immunization is the most effective measure to prevent the transmission of HBV [1,2]. In 2014, the World Health Organization (WHO) reaffirmed the need for hepatitis $B$ vaccines to become an integral part of national immunization schedules [2]. WHO recommends a birth dose within 24 hours of birth to prevent perinatal and early horizontal HBV transmission [1,2]. The birth dose should be followed by 2 or 3 doses of monovalent or multivalent hepatitis $B$ vaccines $[1,2]$.

The widespread use of hepatitis B vaccine in infants has considerably reduced the incidence of new chronic HBV infections [2].

In Nigeria, Hepatitis B vaccination was started in 2004 and currently 3 doses are administered at birth, 6 weeks and at 14 weeks [3]. The most recent estimate of Hepatitis $B$ vaccination coverage at birth with valid evidence is $11 \%$ [4] and $49 \%$ for 3rd dose of Hepatitis B vaccine in the country (Hер3) [5] Demand, supply and systemic side barriers have impacted negatively on vaccination in Nigeria [3-5].

Low level of community participation, inadequate cold chain infrastructure and poor funding for routine immunization amongst other factors remain barriers to improving immunization coverage in Nigeria [3-5].

Worldwide, the majority of persons with $\mathrm{CHB}$ were infected at birth or in early childhood $[2,3]$.

In the absence of prophylaxis, a large proportion of viraemic mothers, especially those who are seropositive for $\mathrm{HBeAg}$, transmit the infection to their $[1,4]$ infants at the time of, or shortly after birth [1]. The risk of perinatal infection is also increased if the mother has acute hepatitis $B$ in the second or third trimester of pregnancy or within two months of delivery. Although, HBV can infect the fetus in utero, this appears to be uncommon and is generally associated with antepartum haemorrhage and placental tears. The risk of developing chronic infection is $90 \%$ following perinatal infection (up to 6 months of age) but decreases to $20-60 \%$ between the ages of 6 months and 5 years $[1,2]$.

Infection with HBV may present as either hepatitis B "e-antigen" (HBeAg) positive or -negative disease [6,7]. Hepatitis B "e-antigen" is seen in many HBeAg-positive children and young adults, particularly among those infected at birth. Children who are HBeAg positive are highly infectious carriers whereas, those who are HBeAg negative, usually anti $\mathrm{HBe}$ positive, have lower risk of transmission $[6,7]$. Being a non-structural protein pro- duced by actively replicating $\mathrm{HBV}, \mathrm{HBeAg}$ is detectable early in the serological course after exposure to HBV, usually after the first months of infection. Clinically, $\mathrm{HBeAg}$ is an index of viral replication, infectivity, inflammation, severity of disease and response to antiviral therapy [6]. HBeAg is encoded by the precore/core Open Reading Frames and the basic core promoter of $\mathrm{HBV}$ controls the transcription of the $\mathrm{preC} / \mathrm{C}$ region [6].

While the earliest [8-15], recent [16-22] and most recent [23-34] reports of Hepatitis $B$ infection in children in Nigeria showed varying prevalence of $0.5 \%$ to $44.7 \%$ and indeed contributed significantly to the epidemiology of Hepatitis B infection in children in the country, these differences in prevalence could be related to age group, population, geographic location, sample size, behavioral cultural factors and laboratory methods used [24]. However, a pooled analysis of HBV prevalence in children and a National survey of Hepatitis B in the general population in the six geo- political zones of $\mathrm{Ni}$ geria showed a prevalence of $11.5 \%$ [35] and $11 \%$ [36] respectively. The northern zones of Nigeria have higher prevalence rate of Hepatitis B with Taraba state having the highest prevalence of $18 \%$ [35].

Most of these studies on HBV prevalence had small sample sizes, have used biomarkers such HBsAg and an$\mathrm{ti}-\mathrm{HBC}$, but the status of Hepatitis $\mathrm{B}$ envelope antigen $[33,34]$ were generally not reported. Hepatitis $B$ envelope epidemiology is crucial and an important marker for perinatal transmission and HBV related disease burden and recently treatment $[1,2,6,37]$.

The objective of this study was to report the dual carriage of Hepatitis B surface and envelope antigen in children in Federal Teaching Hospital Gombe from 2000 to 2015.

\section{Methodology}

\section{Study area}

Gombe is the capital of Gombe state. It is one of the six states that comprise North East Geopolitical zone in the Nigeria and one of the geopolitical zones with the highest levels of poverty and worse maternal and child health indices [5].

\section{Study setting}

This study was conducted in Federal Teaching Hospital Gombe, a 500 bed hospital serving Gombe and neighboring states. The Federal Teaching Hospital, Gombe (FTHG) started providing services in the year 2000 and serves an estimated 20 million people. It has emerged as a Centre for treatment, teaching and research in the sub region with large patient referrals especially in the wake of the daunting security challenges of Boko Haram insurgency confronting the neighbouring states of Borno, Yobe and Adamawa. The FTHG is a regional Centre for sickle cell disease, with accreditation for post graduate training of the West African and National post 
graduate colleges in Radiology, Anesthesia, Surgery, Obstetrics and Gynaecology, Paediatrics. Internal Medicine has sub specialty training in Cardiology and infectious disease.

\section{Study population}

All children 0-18 years who presented to the Paediatrics out-patient department and those that were admitted irrespective of their HIV and or Hepatitis $C$ viral status and who had Hepatitis B and/or Hepatitis B envelope antigen test from 2000 to 2015.

\section{Laboratory methods}

All children were tested using the Hospital standard for Hepatitis B surface antigen test strip. The ACON HBsAg (ACON Laboratories, Incorporated San Diego, California, USA) is a rapid one step test for the qualitative detection of Hepatitis $B$ surface Antigen and Hepatitis $B$ envelope antigen in serum or plasma. The HBsAg test strip has a relative sensitivity, greater than $99.8 \%$ and specificity of $99.7 \%$ [38].

The ACON HBeAg (ACON Laboratories, Incorporated San Diego, California, USA). The HBeAg EIA Test Kit is a one-step enzyme immunoassay for the qualitative detection of Hepatitis B Envelope Antigen ( $\mathrm{HBeAg}$ ) in human serum or plasma.

\section{Principle}

The ACON HBsAg One Step Test is a qualitative, solid phase, two site sandwich immunoassay for the detection of Hepatitis B surface Antigen ( $\mathrm{HBsAg}$ ) and enve- lope antigen in serum or plasma [38]. The membrane is pre-coated with anti-HBsAg antibodies on the test line region and anti-mouse antibodies on the control region. During testing the serum or plasma samples reacts with dye conjugate (mouse anti-HBsAg antibody-colloidal gold conjugate) which has pre-coated in the test strip. The mixture migrated upwards on the membrane chromatographically by capillary action to react with anti-HBsAg antibodies on the membrane and generates a red line. Presence of this red line indicates a positive result, while its absence indicates a negative result. Regardless of the presence of $\mathrm{HBsAg}$ as the mixtures continues to migrate across the membrane to the immobilized goat anti-mouse region, a red line at the control region will always appear. The presence of this red line serves as verification for sufficient sample volume and proper flow as a control for the reagents [38].

\section{HBeAg principle}

$\mathrm{HBeAg}$ in the sample first bound to anti-HBe antibodies coated on the micro-particles, and then the bound HBeAg was detected upon addition of anti-HBe antibodies conjugated to alkaline phosphatase. The HBeAg levels were evaluated using ratios of sample to cut-off values ( $\mathrm{S} / \mathrm{CO}$ ), and $\mathrm{HBeAg}$ positivity was suggested if the $S / C O$ was $\geq 1.0$. Verification of test results was carried out by randomly retesting $5 \%$ of the specimens using the same kit [38].

\section{Data Collection}

Records of Hepatitis B surface and envelope antigen results of children in Federal Teaching Hospital, Gombe

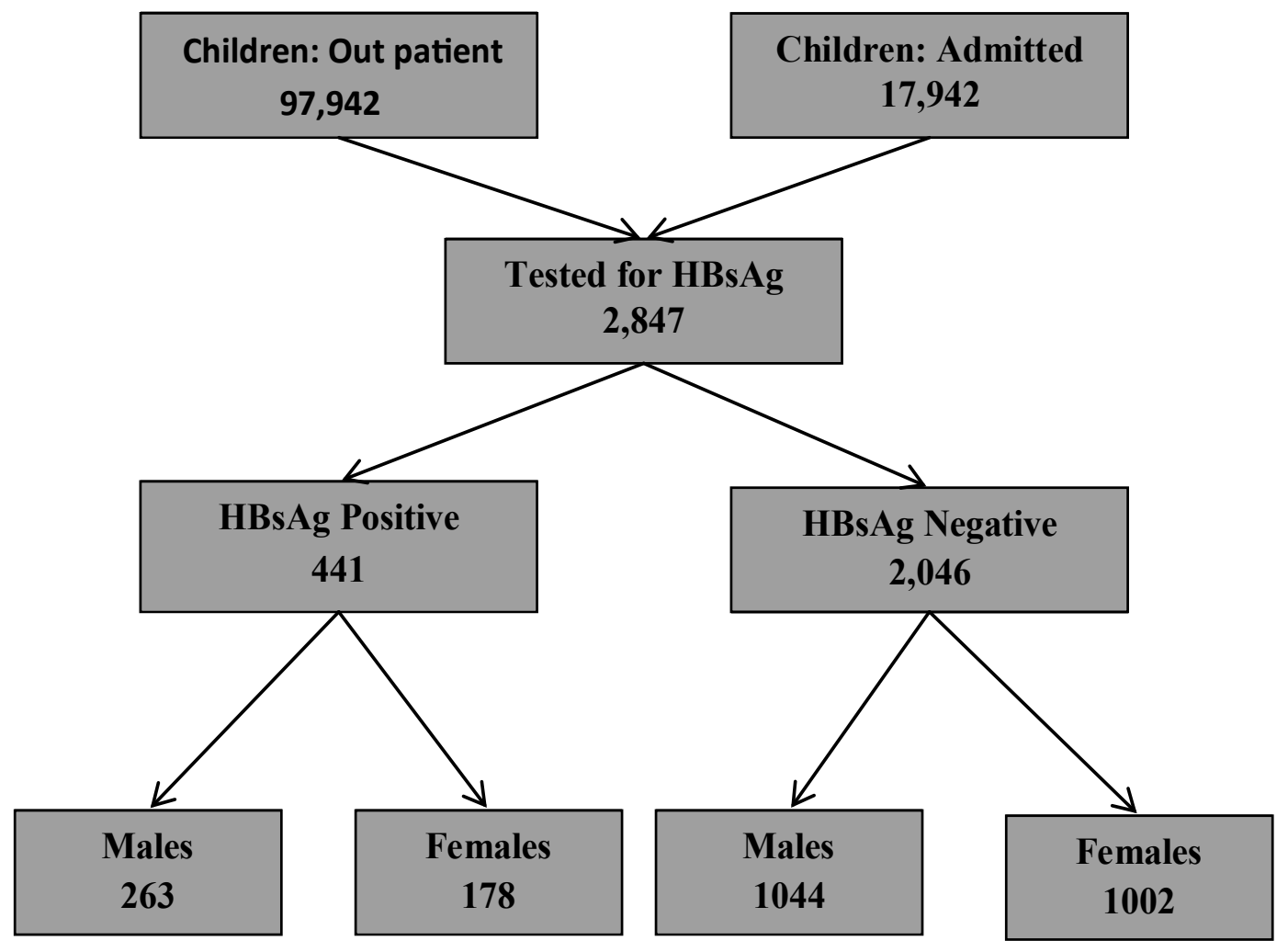

Figure 1: Children 0-18 years tested for Hepatitis B in Federal teaching Hospital Gombe 2000-2015. 
between 2000 and 2015 were retrieved. Variables analysed included age, sex, year, month, and hepatitis B surface and envelope antigen test results.

\section{Data Analysis}

All records were imputed into Epi info Version 3.2 and analysed.

\section{Ethical Clearance}

Clearance for this study was received from the Research and Ethical committee of the Federal Teaching Hospital Gombe.

\section{Results}

During the study period from 2000 - 2015, 97942 and 17942 children were seen in Paediatric outpatient and admitted respectively. 2487 children were tested for Hepatitis B surface antigen; males accounted for 1307 (52.6\%) and females 1180 (47.4\%) (Figure 1).

Of these children tested, $441 / 2487$ (17.7\%) were positive for Hepatitis $B$ surface antigen $\left(x^{2}=10.788 p\right.$ $<0.001$ ), with a male to female ratio of 1.5: 1 (Table 1 ).
The prevalence of Hepatitis B increased with age (Figure 2) with adolescents having the highest prevalence of $19.5 \%$. Adolescents' males have higher prevalence of Hepatitis B than their female counterparts. The difference in age and sex were statistically significant (Table 2).

Hepatitis B e antigen was tested for in $241 / 441$ (54.6\%) of children who tested positive for Hepatitis B surface antigen and 99/241 (41.1\%) of children tested were $\mathrm{HBe}$ antigen positive (Table 3 ). Figure 3 shows the age distribution of dual infection with Hepatitis B surface and e antigens.

Table 4 showed that males were as twice as likely to be e antigen positive as females but this was not statistically significant. ( $\left.X^{2}=3.560, P=0.059\right)$. Age group 1- 4 demonstrated the highest prevalence of e antigen. $\left(X^{2}=1.843 P=0.606\right)$. The sex distribution of e antigen positivity was highest in males for age group $10-18$ and this was statistically significant. $\left(X^{2}=9251, P<0.002\right)$.

\section{Discussion}

This study reports the highest number of children

Table 1: Age and Sex distribution of children 0-18 years screened for Hepatitis B.

\begin{tabular}{|l|l|l|l|}
\hline \multirow{2}{*}{} & \multicolumn{3}{|c|}{ Sex } \\
\cline { 2 - 3 } Number screened for Hepatitis B & Male & Female & $2487(100)$ \\
\hline $\begin{array}{l}\text { Age distribution of children } \\
\text { Screened for Hepatitis B Age group (Years) }\end{array}$ & $1307(52.6)$ & $1180(47.4)$ & \\
\hline$<1$ & & & $57(2.3)$ \\
\hline $1-4$ & $38(2.9)$ & $19(1.6)$ & $282(11.3)$ \\
\hline $5-9$ & $177(13.5)$ & $105(8.9)$ & $519(20.9)$ \\
\hline $10-18$ & $307(23.5)$ & $212(18.0)$ & $1629(65.5)$ \\
\hline
\end{tabular}

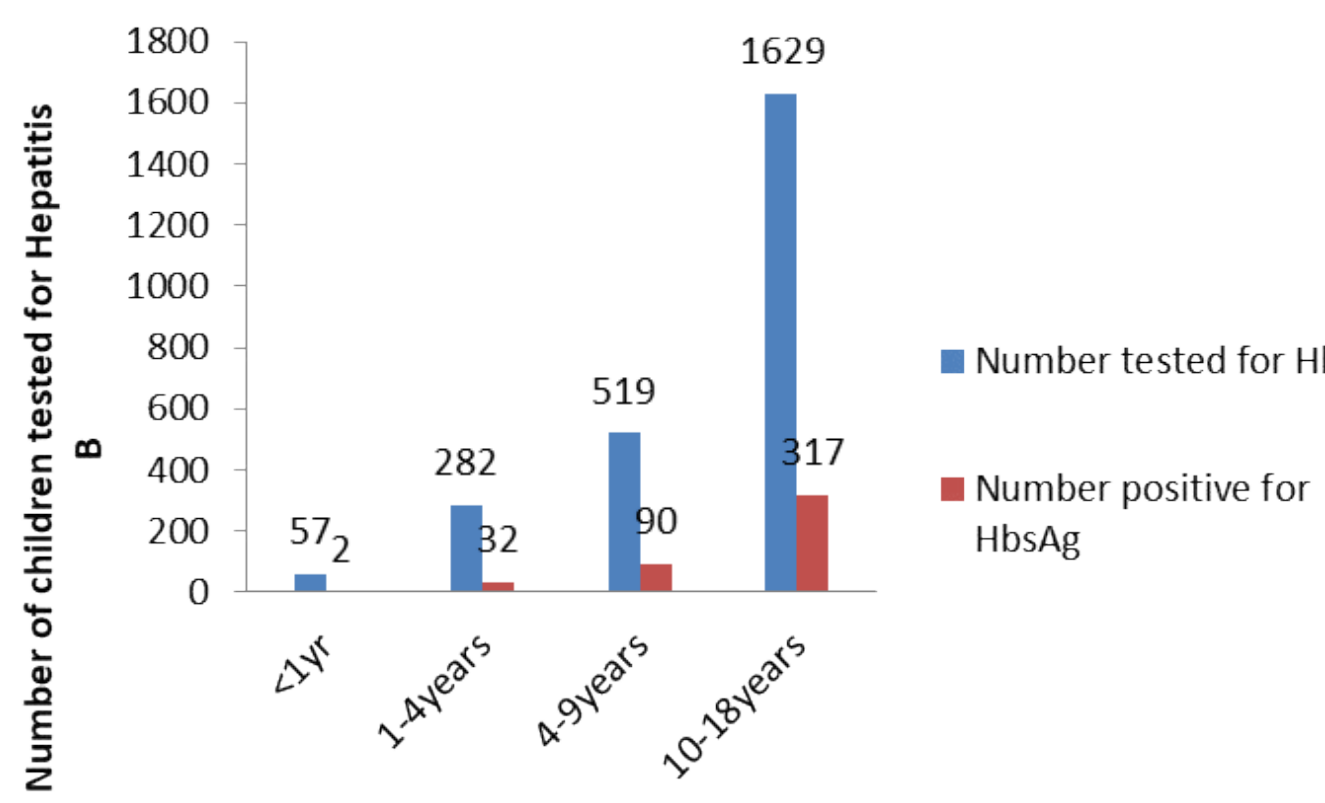

\section{Age group}

Figure 2: Children 0- 18 years tested for and positive for Hepatitis B surface antigen. 
Table 2: Age and Sex distribution of test results of children 0-18 years screened for HBsAg.

\begin{tabular}{|c|c|c|c|c|}
\hline Sex & HBsAg Positive (\%) & HBsAg Negative (\%) & $\mathbf{x}^{2}$ & $\mathbf{P}$ \\
\hline Males & $263(20.1)$ & 1044 (79.9) & 10.788 & 0.001 \\
\hline Females & $178(15.1)$ & 1002 (84.9) & & \\
\hline Total & $441(17.7)$ & 2046 (82.3) & & \\
\hline Age group (Years) & HBsAg Positive (\%) & HBsAg Negative (\%) & $\mathbf{x}^{2}$ & $\mathbf{P}$ \\
\hline$<1$ & $2(3.5)$ & $55(96.5)$ & 19.172 & 0.001 \\
\hline $1-4$ & $32(11.3)$ & $250(88.7)$ & & \\
\hline $5-9$ & $90(17.3)$ & $429(82.7)$ & & \\
\hline $10-18$ & $317(19.5)$ & $1312(80.5)$ & & \\
\hline \multicolumn{5}{|l|}{ Age group and Sex } \\
\hline$<1 \mathrm{yr}$ & HBsAg Positive (\%) & HBsAg Negative (\%) & $x^{2}$ & $P$ \\
\hline Male & $1(2.6)$ & $37(97.4)$ & 0.259 & 0.611 \\
\hline Female & $1(5.3)$ & $18(94.7)$ & & \\
\hline \multicolumn{5}{|l|}{ 1- 4 yrs } \\
\hline Male & $23(13.0)$ & $154(87.0)$ & 1.282 & 0.258 \\
\hline Female & $9(8.2)$ & $96(91.4)$ & & \\
\hline \multicolumn{5}{|l|}{$5-9$ yrs } \\
\hline Male & $47(15.3)$ & $260(84.7)$ & 2.164 & 0.141 \\
\hline Female & $43(20.3)$ & $169(79.7)$ & & \\
\hline \multicolumn{5}{|l|}{$10-18$ yrs } \\
\hline Male & $193(24.6)$ & $592(75.4)$ & 25.403 & 0.001 \\
\hline Female & $124(14.7)$ & $720(85.3)$ & & \\
\hline
\end{tabular}

Table 3: Age and Sex distribution of children 0-18 years HBsAg + and screened for HbeAg.

\begin{tabular}{|c|c|c|c|c|}
\hline Sex & e Antigen Tested (\%) & e Antigen Not tested (\%) & $x^{2}$ & $\mathbf{P}$ \\
\hline Male & $152(57.8)$ & $111(42.2)$ & 2.602 & 0.107 \\
\hline Female & $89(50.0)$ & $89(50.0)$ & & \\
\hline Total & $241(54.6)$ & $200(45.4)$ & & \\
\hline Age group & e Antigen Tested (\%) & e Antigen Not tested (\%) & $\mathbf{x}^{2}$ & $\mathbf{P}$ \\
\hline$<1$ & $2(100)$ & $0(0.0)$ & 0.624 & 1.756 \\
\hline $1-4$ & $18(56.2)$ & $14(43.8)$ & & \\
\hline $5-9$ & $48(53.3)$ & $42(46.7)$ & & \\
\hline $10-18$ & $173(54.6)$ & $144(45.4)$ & & \\
\hline
\end{tabular}

Table 4: Age and Sex distribution of children 0-18 years $\mathrm{HBsAg}+$ and $\mathrm{HBeAg}$ positive.

\begin{tabular}{|c|c|c|c|c|}
\hline Sex & e Antigen Positive (\%) & e Antigen Negative (\%) & $\mathbf{x}^{2}$ & $\mathbf{P}$ \\
\hline Male & $69(45.7)$ & $82(54.3)$ & 3.560 & 0.059 \\
\hline Female & $30(33.3)$ & $60(66.7)$ & & \\
\hline Age group & e Antigen Positive (\%) & e Antigen Negative (\%) & $\mathbf{x}^{2}$ & $\mathbf{P}$ \\
\hline$<1$ & $1(50.0)$ & $1(50.0)$ & 1.024 & 0.796 \\
\hline $1-4$ & $9(50.0)$ & $9(50.0)$ & & \\
\hline $5-9$ & $21(43.8)$ & $27(56.2)$ & & \\
\hline $10-18$ & $68(39.3)$ & $105(60.7)$ & & \\
\hline \multicolumn{5}{|c|}{ Sex and Age group } \\
\hline$<1 \mathrm{yr}$ & HBsAg and e Positive (\%) & HBsAg and e Negative (\%) & $x^{2}$ & $P$ \\
\hline Male & $0(0)$ & $0(0)$ & & \\
\hline Female & $1(50.0)$ & $1(50.0)$ & & \\
\hline $1-4$ yrs & & & & \\
\hline
\end{tabular}




\begin{tabular}{|l|l|l|l|l|}
\hline Male & $5(45.5)$ & $6(54.5)$ & 0.234 & 0.629 \\
\hline Female & $4(57.1)$ & $3(42.9)$ & & \\
\hline $5-9$ yrs & & & 1.008 & 0.315 \\
\hline Male & $11(38.0)$ & $9(47.4)$ & \\
\hline Female & $10(52.9)$ & & \\
\hline $10-18$ yrs & & $58(52.3)$ & 9.251 & 0.002 \\
\hline Male & $53(47.7)$ & $47(75.8)$ & & \\
\hline Female & $15(24.2)$ & & \\
\hline
\end{tabular}

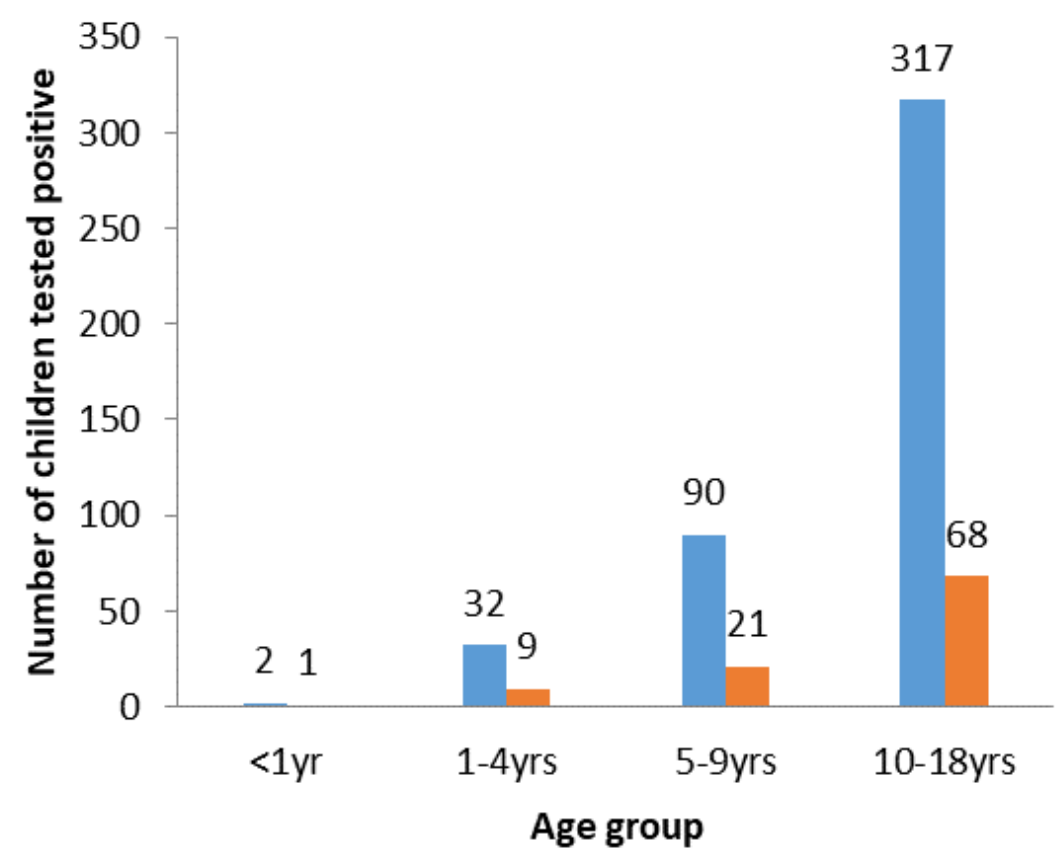

HbsAg positive

HbeAg positive

Figure 3: Children 0-18 years positive for both Hepatitis $B$ and e antigens.

screened for both Hepatitis $b$ and e antigens from a health facility not only in Nigeria but the sub region. The prevalence of Hepatitis B surface antigen of $17.7 \%$ in children 0-18years in this study is higher than pooled prevalence of a meta-analysis in children of $11.5 \%$ in the country [36]. This was also higher than the national survey prevalence of $11 \%$ in the general population conducted in 2013 by the FMOH [35]. The higher prevalence in our report might be related to the population studied and indeed contributed by the very low levels of childhood immunization, endemic poverty and poorest maternal and child indices of any region in Nigeria [3-5].

Nigeria like of the whole of Africa is hyper endemic for Hepatitis $B$ with the prevalence of $\mathrm{HBsAg}>8 \%$ in the general population $[1,2,35]$.

A pooled prevalence of Hepatitis B Virus of $12.3 \%$ in general population was reported in Ghana but most studies were concentrated in adult populations giving little information about HBV prevalence in children [39]. Similarly, systematic review and meta-analysis in Cameroun, of hepatitis B virus infection from 2000-2016 showed a pooled prevalence of $11.2 \%$ in adults with no seroprevalence data in children [40].

There was paucity of Hepatitis B prevalence data in children in Systematic review and meta- analysis in Burkina Faso 1996 to 2017 [41] and Malawi 1990-2018 [42]. However a prevalence of Hepatitis of $4.2 \%$ in newborns and 2.2\% in HIV infected children were reported in Burkina Faso [41] and Malawi [42] respectively.

Recent reports of Hepatitis B in different children populations reported prevalence of $12.3 \%$ in Ghana [43], $13.7 \%$ in Sierra Leone [44], 20.5\% in Cameroon [45] and 4\% in Cote Dviore [46]. However, these reports had small sample sizes, limited age and sex disaggregation and duration of study but significant contributions to Hepatitis B epidemiology in the sub-region.

A hospital based study reported HBsAg prevalence of $1.9 \%$ in 33 of 1783 fully immunized children in Central African Republic, Cameroon and Senegal with country prevalence of $5.1 \%, 0.7 \%$ and $0.2 \%$ respectively. These were fully immunized children with Hepatitis $B$ vaccine [47]. In Cote d ivoire, the prevalence of Hepatitis B surface antigen was found to be $13.4 \%$ in children less than 20 years of age who were volunteers or patients subject [48].

While our study subjects comprised of volunteers, patients and children who may or may not have been immunized, the prevalence of Hepatitis B in our study 
is higher than these reports [24,43-46]. This high prevalence in our study would no doubt be related to low level of routine immunization coverage of $23 \%$ and specifically of Hepatitis b vaccine in Gombe State and Nigeria respectively [44]. In addition some of our study subjects were recruited before the introduction of Hepatitis $B$ Vaccine in Nigeria in 2004. A significantly high prevalence of hepatitis $B$ in proportion of children below five years in our study suggests perinatal transmission due to lack of immunization or early childhood transmission $[1,2]$.

Country level infant immunization programme for Hepatitis B was first implemented in Africa in Gambia in 1990 and demonstrated a reduced HBV burden in children, with $\mathrm{HBsAg}$ prevalence decreasing from $10.0 \%$ to $0.6 \%[49,50]$. Non-nationally representative data from Cameroon, Nigeria, Senegal and Ghana showed a decline in post vaccine Hepatitis $B$ prevalence rate [51]. Hepatitis $B$ vaccination in children has had significant impact on infection and associated liver disease $[52,53]$.

The prevalence of HBsAg in children increased with increasing age with adolescents having the highest infection in our study. This is similar to earlier [13-15] and recent reports [26,32-34] in Nigeria. HBsAg infection increased with age in children with peak in 10-19 year age group in the Nigeria national survey [54]. Most recent reports of Hepatitis B in children from Ghana [43], Sierra Leone [44], Cameroon [45], and Cote Dviore [46] showed age related increase in prevalence.

Most hepatitis B virus (HBV) infections in Sub-Saharan African infants and children are acquired through horizontal transmission $[55,56]$. At least $50 \%$ of infections in children cannot be accounted for by mother-to-infant transmission and, in many endemic regions, prior to the introduction of neonatal vaccination, the prevalence peaked in children $7-14$ years of age $[1,2]$.

In especially endemic areas, Children infected perinatally with Hepatitis B can be a source of horizontal infection for siblings and playmates [57,58]. Intra-familial horizontal transmission of Hepatitis B can occur during sharing of; bath towels, chewing gum or candies, toothbrushes and biting of finger nails in conjunction with scratching the backs of carriers of HBsAg [56].

Common risk factors for hepatitis $B$ infection in the Nigeria National survey were uvulectomy, presence of tribal marks, sharing of sharp objects, and circumcision, which is performed traditionally on many Nigerian males [54].

Adolescents infected during childhood or in this period with $\mathrm{HBV}$ are at risk of infecting others especially through sexual transmission as it is a dominant route of horizontal transmission during adolescence $[59,60]$.

In our study, more male children were infected with HBV than females and this was statistically significant. This is similar to most finding in Nigerian studies
$[14,17,19,22,24]$ and reports from Burkina Fasso [41], Ghana [43], Sierra Leone [44] Cameroon [45], and Togo [61].

Plasma clearance rate for $\mathrm{HBsAg}$ in males is slower compared to females and females were said to have elaborated more antibodies to HBsAg than males. Differences in tribal and sexual behaviours between males and females may account for higher percentage of HBsAg positive males with HBV chronic infection [62-64]. An Altered Pattern of Liver Apolipoprotein A-I Isoforms is implicated in male chronic Hepatitis B progression [65].

Shimakawa $Y$, et al. reports that sero-clearance of HBsAg is uncommon, occurs at a rate of about $1 \%$ per year $[66,67]$. Earlier age at HBV infection is associated with an increased risk of Hepatocellular carcinoma through persistence of viral replication $[66,67]$.

The prevalence of Hepatitis $b$ envelope antigen among Hepatitis $b$ infected children in this study was $41.7 \%$. This may be a gross underestimation of the prevalence of $\mathrm{HBeAg}$ amongst $\mathrm{HBsAg}$ carrier children as less half of the children were screened for the envelope antigen.

Before the availability of The HBV Combo Rapid Test Cassette Kit for the rapid diagnosis of HBsAg and other markers of hepatitis $B$ ( $\mathrm{HBeAg}$; $\mathrm{AbHBe}, \mathrm{AbHBs}$ and $A b H B c)$, the test kits for hepatitis $b$ and envelope antigen were separate in our environment. It's probable a combination of factors including cost of envelope antigen test, low awareness on the significance of the test and or inadequate patient counseling [1,2] may have accounted for why only a third of HBV chronic carriers tested for this marker of viral replication, infectivity, inflammation, severity of disease and response to antiviral therapy.

The expression of $\mathrm{HBeAg}$ is one of the major factors influencing the frequency and mode of transmission of HBV $[6,66]$. Indeed maternal HBeAg is a stronger predictor of perinatal transmission than maternal HBsAg [68].

The prevalence of Hepatitis $B$ envelope antigen in children infected with Hepatitis B has largely not been reported in Nigeria. Ndako, et al. in Jos Nigeria, reported an envelope antigen prevalence of $4 \%$ among 58 children with hepatitis B. Hepatitis B was found in $25 \%$ of these children [33]. A prevalence of Hepatitis B e antigen of $27 \%$ was reported in Zaria Nigeria by Sani and coworkers amongst 95 children with Hepatitis B disease [34]. In both studies sample sizes were small and there was no age and sex disaggregation. Among other factors, $\mathrm{HBeAg}$ expression is influenced by HBV genotypes and sub genotypes $[6,66]$.

Forbi. et al. [23] reported a prevalence of HBe antigen of $72.7 \%$ in 22 children < 10 -years-old and $42.3 \%$ in children 10-20years with Hepatitis B in North central Nigeria. In our study, the prevalence rate of hepatitis 
Be antigen in children less than 10 years of age and adolescents were $54 \%$ and $39 \%$ respectively. These prevalence rates were lower than the report by Forbi, et al, but higher than report by both Ndako, et al. [33] and Sani and coworkers [34] in Nigeria While these studies $[23,34,34]$ had small sample sizes and limited age ranges of children thereby not the representative estimate of $\mathrm{HBeAg}$ prevalence, they provided a glimpse of the burden of $\mathrm{HBe}$ antigen in children in the country in the absence of a representative national data. The National Seroprevalence survey of Hepatitis B report in Nigeria in 2016 did not determine HBe antigen status of seropositive individuals [54].

$\mathrm{HBeAg}$ estimates are crucial for understanding the epidemiology of HBV and for prioritizing access to treatment for chronic HBV infection especially in the wake of WHO scaling of early diagnosis and treatment $[2,6,66]$.

Ott, et al. [69] in 1990 reported hepatitis be prevalence of $55.6 \%$ and $42.2 \%$ in females of $0-9$ years and 10-19 years respectively in the West Africa sub region. Our study prevalence rate of $65 \%$ in the age group $0-9$ is higher than the report by Ott, et al. [69]. In the adolescent females, Hepatitis Be prevalence of $22 \%$ in our study is lower than $42 \%$ reported by Ott, et al. Our sample size in this age group was smaller.

These studies [24,34,35] showed that Hepatitis Be antigen prevalence is age dependent with higher prevalence in young children.

This age dependent Hepatitis Be prevalence was also demonstrated by Ott, et al. in 2005 [69] and showed prevalence of $55.3 \%$ in $0-9$ years and $41.1 \%$ in $10-19$ year females. This is similar to our study that showed $\mathrm{HBe}$ prevalence to be decreasing with increasing age in females.

While the exact function of $\mathrm{HBeAg}$ has not been elucidated, it has been shown to be an immunoregulatory protein, which acts as a tolerogen and an immunogen triggers an interleukin-1 response and regulates toll-like receptor 2 (TLR-2) expression [6].

In Cote $d^{\prime}$ voire a prevalence of $82.4 \%$ of $\mathrm{HBe}$ was reported among 34 children co-infected with HIV and Hepatitis B, while this is higher than our overall prevalence, however the sample size was small and had a limited age range [70].

Our overall Hepatitis B e antigen prevalence of $41.7 \%$ in children with Hepatitis B surface antigen is lower than the $66.3 \%$ reported in children and adolescents in Brazil [71]. In this study, the highest e antigen prevalence of $69.5 \%$ was in children $0-4$ years thereafter declining to $50 \%$ in children $15-18$ years of age. No sex disaggregation was reported. This decline is similar to our report; however our $\mathrm{HBe}$ antigen prevalence rates were lower across all age groups.

During the natural course of chronic hepatitis $B$ virus
(HBV) infection, patients with high serum levels of viral DNA and hepatitis B e antigen ( $\mathrm{HBeAg}$ ) may gradually and spontaneously clear $\mathrm{HBeAg}$ and develop antibody to $\mathrm{HBeAg}$. In African countries, $\mathrm{HBeAg}$ seroconversion is more frequent, occurring at an annual rate of $14 \%-16 \%$ and half losing it by puberty $[6,66,72,73]$.

In a multicenter paediatric cohort study of 323 children with chronic Hepatitis infection in Canada and USA, Schwartz, et al. [74] reported a hepatitis b e antigen prevalence of $74 \%$ with $65 \%$ being female. While this prevalence is higher than our finding but similar to the report by Forbi in Nigeria, the implication for mother to child transmission of $\mathrm{HBV}$ in our region is significant especially as HBV screening is not routinely conducted at antenatal care, HBV DNA viral load test is generally absent and access to Hepatitis B immunoglobulin or anti-viral HBV therapy for infected individuals are severely limited $[75,76]$. Though the risk of mother to child transmission in sub Saharan Africa is low 38\% compared to Asia, annually 367,250 infants are infected with HBV which is approximately twice the number of children newly infected with HIV in the sub-region [77].

In Africa where the prevalent genotypes are sub genotype $A 1$, genotypes $D$ and $E$, carriers of these genotypes seroconvert early $[6,66,73]$.

Achieving the WHO regional target for Africa of $<2 \%$ HBsAg prevalence in children less than 5 years by 2020 requires leadership commitment that ensures an effective and efficient Routine immunization programme [78].

\section{Conclusion}

The prevalence of both HBsAg and HBV e antigen in children in our report is high and in particular the prevalence of $\mathrm{HBV}$ e antigen in our study population may have been under estimated. Clinical and economic implications are profound as its epidemiology is crucial in HBV transmission and prioritizing access to treatment especially in Sub Saharan Africa.

\section{Limitation}

The limitations of our study are several: we could not determine if $\mathrm{HBsAg}$ positivity was new or chronic infection (HBsAg carriage for $>6$ months). Anti-HBs status could have determined non exposure to $\mathrm{HBV}$ requiring preventive HBV vaccine. Not report liver function and liver status including Biopsy and Hepatitis B viral load tests results. Viral load test started in 2018 in our centre and currently beyond the reach of most patients (\$72).

\section{Recommendations}

Universal HBV testing in Antenatal clinics and neonatal HBV immunoglobulin should be implemented in $\mathrm{Ni}$ geria. Neonatal Hepatitis $B$ vaccination and indeed Routine immunization requires urgent strengthening and legislation making immunization in Nigeria mandatory 
must be a top legislative agenda. A prospective nationally representative multicenter collaborative longitudinal study on Viral Hepatitis Epidemiology and treatment is urgently required in Nigeria.

\section{Acknowledgments}

We wish to acknowledge Hajiya Fatima Y Aliyu and Hajiya Zainab Danmalam of the data unit of paediatrics department for extracting the data.

\section{Conflict of Interest}

The authors declare no conflict of interest

\section{Author Contributions}

Isaac Warnow Elon: Conceived of the study and study design, developed the first manuscript draft, and critically reviewed all drafts of the manuscript.

Ajani Ayomikun: Oversaw the study design, conducted quantitative data analysis, developed the first manuscript draft, and critically reviewed all drafts of the manuscript.

Jalolliya, Alkali Yaya: Oversaw the study design and critically reviewed and commented on the final manuscript.

Joshua Difa, Oyeniyi Christianah: Conducted quantitative analysis and commented on all drafts of the manuscript.

Danlami Halilu: Critically reviewed all results and commented on the final results of manuscript.

\section{References}

1. World Health Organization (2015) Guidelines for the prevention, care and treatment of persons with chronic hepatitis infection.

2. World Health Organization (2017) Global hepatitis report.

3. National Programme on Immunization and Partners. Five years National Strategic Plan 2003-2007 (2002). National Programme on Immunization 19-20.

4. Nigeria: WHO and UNICEF estimates of immunization coverage: 2016 revision

5. National Bureau of Statistics (NBS) and United Nations Children's Fund (UNICEF) 2017 Multiple Indicator Cluster Survey 2016-17, Survey Findings Report. Abuja, Nigeria: National Bureau of Statistics and United Nations Children's Fund.

6. Kramvis A (2016) The clinical implications of hepatitis B virus genotypes and $\mathrm{HBeAg}$ in pediatrics. Rev Med Virol 26: 285-303.

7. Mike Sharland (2011) Editor. Royal College of Paediatrics and Child Health. Manual of childhood infections. 3rd Edition. The blue book. Hepatitis B, Management and treatment. Oxford University Press 564-570.

8. Francis II, Smith JA (1973) Australia antigen AU in school children in Ibadan Nigeria. J Trop Med Hyg 76: 19-22.

9. Williams AO, Fabiyi A, Williams Al, Gubpta B, O Connor $\mathrm{IH}$, et al. (1973) Hepatitis in Nigerian Children. E Afr Med J 50: $521-528$.
10. Johnson AD, Sodeide O, Adelola HA, Ayoola EA (1986) Nig J Paed 13: 83- 86.

11. Fakunle YM, Abdurrahman MB, Whittle HC (1981) Hepatitis-B virus infection in children and adults in Northern $\mathrm{Ni}$ geria: a preliminary survey. Trans R Soc Trop Med Hyg 75: 626-629.

12. Kaine WN, Okafor GO (1983) Hepatitis B surface antigen in Nigerian children with sickle cell anaemia. J Trop Paediatr 29: 55-57.

13. Abiodun PO, Omoike IU (1990) Hepatitis B antigenaemia in children in Benin City. Nig J Paediatr 17: 27-31.

14. Abiodun PO, Okolo SN (1991) Hepatitis B surface antigenamia in and outpatient children at University of Benin Teaching Hospital. Nig J Paediatr 18: 105-112.

15. Bada AS, Olatunji PO, Adewuyi JO, Iseniyi JO, Onile BA (1996) Hepatitis B surface antigenaemia in Ilorin, Kwara State, Nigeria. Cent Afr J Med 42: 139-141.

16. Chukwuka JO, Ezechukwu CC, Egbuonu I (2003) Cultural influences on hepatitis B surface antigen seropositivity in primary school children in Nnewi. Nig J Paediatr. 30: 140142.

17. Bukbuk DN, Barsi AP, Mungoro ZM (2005) Seroprevalence of hepatitis surface antigen among primary school pupils in rural Hawal valley, Borno State, Nigeria. Nigerian Journal of Community Medicine and Primary Health care 17: 20-23.

18. Olajide OA, Juliet OI, Mathew OK, Ajuawo A (2007) Risk factors and prevalence of hepatitis $B$ surface antiginaemia in mothers and their preschool age children in Ilorin, Nigeria. Therapy 4: 67-72.

19. Alikor EA, Erhabor ON (2007) Seroprevalence of hepatitis $B$ surface antigenaemia in children in a tertiary health institution in the Niger delta of Nigeria. Nig J Med 16: 250-251.

20. Ashir GM, Rabasa Al, Gofama MM (2007) Seroprevalence of hepatitis B surface antigenaemia in children attending the University of Maiduguri Teaching Hospital. Niger J Pediatr 34: 85-89.

21. Ugwuja E, Ugwu N (2009) seroprevalence of Hepatitis B Surface Antigen and Liver Function Tests among Adolescents in Abakaliki, south Eastern Nigeria. The Internet $\mathrm{J}$ Tropical Med 6.

22. Emechebe GO, Emodi IJ, Ikefuna AN, llechukwu GC, Igwe WC, et al. (2009) Hepatitis B virus infection in Nigeria - A review. Niger Med J 50: 18-22.

23. Forbi JC, Iperepolu OH, Zungwe T, Agwale S (2012) Prevalence of Hepatitis B e Antigen in Chronic HBV Carriers in North-central Nigeria. J health popul nutr 30: 377-382.

24. Okonko I, Okerentugba P, Innocient AH (2012) Detection of Hepatitis B Surface Antigen (HBsAg) among children In Ibadan, Southwestern Nigeria. Int J Infect Dis 10.

25. Sadoh AE, Sadoh WE (2013) Serological markers of hepatitis $B$ infection in infants presenting for their first immunization. Niger J Paeadiatr 40: 248-253.

26. David OM, Oluduro AO, Ariyo AB, Ayeni D, Famurewa O (2013) Sero-epidemiological survey of hepatitis B surface antigenaemia in children and adolescents in Ekiti State, Nigeria. J Publ $\mathrm{H}$ and Epid 5: 11-14.

27. Sadoh AE, Ofili A (2014) Hepatitis B infection among Nigerian children admitted to a children's emergency room. African Health Sciences 14: 377-383.

28. Jibrin B, Jiya NM, Ahmed H (2014) Prevalence of Hepatitis B surface Antigen in children with sickle cell anemia. Sahel Med J 17: 15-18. 
29. Donbraye E, Japhet MO, Adesina AO, Abayomi OA (2014) Prevalence of asymptomatic hepatitis $B$ virus surface antigenemia in children in Ilesha, Osun state, south-Western Nigeria. Afr J Micro Res 8: 2329-331.

30. Uleanya ND, Obidike EO (2015) Prevalence and risk factors of hepatitis $B$ virus transmission among children in Enugu, Nigeria. Nig J of Paediatr 42.

31. Eke CB, Ogbodo SO, Ukoha OM, Ibekwe RC, Asinobi IN et al. (2015) Seroprevalence and Risk Factors of Hepatitis $B$ Virus Infection among Adolescents in Enugu, Nigeria. $J$ Trop Pediatrn 61: 407-413.

32. Ikobah J, Okpara H, Elemi I, Ogarepe Y, Udoh E, et al (2016) The prevalence of hepatitis B virus infection in Nigerian children prior to vaccine introduction into the National Programme on Immunization schedule. Pan Afr Med J 23 128

33. Ndako JA, Onwuliri FC, Botson ID (2016) Studies on the serological markers of hepatitis $B$ virus infection among children in Riyom LGA, North Central Nigeria. Int J Health Sci Res 6: 405-414.

34. Sani MM, Hafsat WI, Sakinatu MA, Ibrahim A, Sani M, et al (2018) Prevalence of hepatitis B viral infection at paediatric gastroenterology clinic of ABUTH, Zaria. Niger J Basic Clin Sci 15: 114-117.

35. Federal Ministry of Health. Prevalence survey of hepatitis B and $\mathrm{C}$ in general population. FMOH. 2013

36. Musa BM, Bussell S, Borodo MM, Samaila AA, Femi OL (2105) Prevalence of hepatitis B virus infection in Nigeria, 2000-2013: A systematic review and meta-analysis. Nig J Clinical Practice 18: 163-172.

37. Shimakawa Y, Njie R, Ndow G, Vray M, Mbaye PS, et al. (2018) Development of a simple score based on $\mathrm{HBeAg}$ and ALT for selecting patients for HBV treatment in Africa. J. Hepatol 69: 776-784.

38. www.aconlabs.com.HbsAg EIA Test kit Package Insert/ hbeAg Test Kit. Accessed 29 February/2020

39. Ofori-Asenso R, Agyeman AA (2016) Hepatitis B in Ghana: A systematic review \& meta-analysis of prevalence studies (1995-2015). BMC Infect Dis 16: 130.

40. Bigna JJ, Amougou MA, Asangbeh SL, N Noumegni SR, Ngo-Malabo EY, et al. (2017) Seroprevalence of hepatitis $B$ virus infection in Cameroon: A systematic review and meta-analysis. BMJ Open 7.

41. Lingani M, Akita T, Ouoba S, Sanou AM, Sugiyama A, et al (2018) High prevalence of hepatitis B infections inBurkina Faso (1996-2017): a systematic reviews with meta-analysis of epidemiological studies. BMC Public Healt 18: 551.

42. Stockdale AJ, Mitambo C, Dean Everett D, Geretti AM, Gordon MA (2018) Epidemiology of hepatitis B, C and D in Malawi: systematic review. BMC Infectious Dis 18: 516.

43. Amidu N, Alhassan A, Obirikorang C, Feglo PK, Majeed S, et al. (2012) Sero-prevalence of hepatitis B surface (HB$\mathrm{sAg}$ ) antigen in three densely populated communities in Kumasi, Ghana J Med and Biomed Sci. 1: 59-65.

44. Ansumana R, Dariano DF, K HJacobsen, Leski TA, Kamin JM, et al. (2018) Seroprevalence of hepatitis B surface antigen (HBsAg) in Bo, Sierra Leone, 2012-2013. BMC Res Notes 11: 113 .

45. Foupouapouognigni $Y$, Mba SAS, Betsem a' Betsem, Rousset D, Froment A, et al. (2011) Hepatitis B and C Virus Infections in the Three Pygmy Groups in Cameroon. J Clini Micro 49: 737-740.
46. Attia KA, Kissi YH, Doffou S, Bangoura AD, Wilson RF, et al. (2013) Prevalence of hepatitis B infection and factors associated in children of Ivorian HBsAg carrier subjects. Open J Gastroenterol 3: 237-240.

47. Rey-Cuille MA, Njouom R, Bekondi C (2013) HBV Exposure in Cameroon, CAR and Senegal. The Pediatr Infect Dis J 32: 10.

48. Kouassi-M'Bengue A, Abdoulaye O, Allah-Kouadio E, Sevede D, Doumbia M, et al. (2017) A very high frequency of hepatitis $B$ and $C$ virus infections during an active screening campaign in Abidjan. Afr J Micro Res 11: 1.

49. Montesano R (2002) Hepatitis B immunization and hepatocellular carcinoma: the Gambia Hepatitis Intervention Study. J Med Virol 67: 444-446.

50. Viviani S, Jack A, Hall AJ, Maine N, Mendy M, et al. (1999) Hepatitis $B$ vaccination in infancy in The Gambia: protection against carriage at 9 years of age. Vaccine 17: 2946-2950.

51. Breakwell L, Tevi-Benissan C, Childs L, Mihigo R, Tohme $R$ (2017) The status of hepatitis B control in the African region. Review: The Pan Afri Med J 27: 17.

52. Kim H, Shin AR, Chung HH, Kim MK, Lee JS, et al. (2013) Recent trends in hepatitis $B$ virus infection in the general Korean population. Korean J Intern Med 28: 413-419.

53. Qu C, Chen T, Fan C, Zhan Q1, Wang Y, et al (2014) Efficacy of neonatal HBV vaccination on liver cancer and other liver diseases over 30-year follow-up of the Qidong hepatitis $B$ intervention study: a cluster randomized controlled trial. PLoS Med 11: e1001774.

54. Olayinka AT, Oyemakinde A, Balogun MS. Ajudua A, Nguku P, et al. (2016) Seroprevalence of Hepatitis B Infection in Nigeria: A National Survey. Am J Trop Med Hyg 95: 902-907.

55. Edmunds WJ, Medley GF, Nokes DJ, O'Callaghan CJ, Whittle HC, et al. (1996) Epidemiologic patterns of hepatitis $B$ virus $(\mathrm{HBV})$ in highly endemic areas. Epidemiol Infect 117: 313-325.

56. Martinson FE, Weigle KA, Royce RA, Weber DJ, Suchindran CM, et al. (1998) Risk factors for horizontal transmission of hepatitis B virus in a rural district in Ghana. American J Epidemiol 147: 478-487.

57. Hsu SC, Chang MH, Ni YH, Hsu HY, Lee CY (1993) Horizontal transmission of hepatitis $B$ virus in children. J Pediatr Gastroenterol and Nutr 16: 66-69.

58. Whittle HC, Bradley AK, McLauchlan K, Ajdukiewicz AB, Howard CR, et al. (1983) Hepatitis B virus infection in two Gambian villages. Lancet 1: 1203-1206.

59. Burnett RJ, Francois G, Kew MC, Leroux-Roels G, Meheus A, et al. (2005) Hepatitis B virus and human immunodeficiency virus co-infection in sub-Saharan Africa: a call for further investigation. Liver International 25: 201-213.

60. Jacobs B, Mayaud P, Changalucha J, Todd J, Ka-Gina G, et al. (1997) Sexual transmission of hepatitis B in Mwanza, Tanzania. Sex Trans Dis 24: 121-126.

61. Banla AK, Gani KT, Halatoko WA, Layibo Y, Akolly K, et al. (2015) Prevalence of the Surface Antigen of Hepatitis $B$ Virus among Youth Aged 15 to 24 in TOGO in 2010. J Infect Dis Ther 3: 238.

62. Price $H$, Dunn D, Zachary $T$, Vudriko $T$, Chirara $M$, et al. (2017) Hepatitis B serological markers and plasma DNA concentrations. AIDS 31: 1109-1117.

63. Blumberg BS (1979) Sex differences in response to hepatitis b virus. Arthritis \& Rheumatism 22: 1261-1266. 
64. Coursaget $P$, Yvonnet $B$, Chotard J, Vincelot $P$, Sarr $M$, et al. (1987) Age- and sex-related study of hepatitis B virus chronic carrier state in infants from an endemic area (Senegal). J Med Virol 22: 1-5.

65. Yang F, Yin Y, Wang F, Zhang L, Wang Y, et al. (2010) An Altered Pattern of Liver Apolipoprotein A-I Isoforms is implicated in male chronic Hepatitis B progression. J Proteome Res 9: 134-143.

66. Shimakawa Y, Yan H-J, Tsuchiya N, Bottomley C, Hall AJ (2013) Association of Early Age at Establishment of Chronic Hepatitis B Infection with Persistent Viral Replication, Liver Cirrhosis and Hepatocellular Carcinoma: A Systematic Review. PLoS ONE 8: e69430.

67. Shimakawa Y, Lemoine M, Njai HF, Bottomley C, Ndow G, et al. (2016) Natural history of chronic HBV infection in West Africa: a longitudinal population-based study from The Gambia. Gut 65: 2007-2016.

68. Shimakawa Y, Bottomley C, Njie R, Mendy M (2014) The association between maternal hepatitis $\mathrm{B}$ e antigen status, as a proxy for perinatal transmission, and the risk of hepatitis B e antigenaemia in Gambian children. BMC Public Health 14: 532.

69. Ott JJ, Stevens JA, Wiersma ST (2012) The risk of perinatal hepatitis $B$ virus transmission: hepatitis $B$ e antigen $(\mathrm{HBeAg})$ prevalence estimates for all world regions. BMC Infect Dis 12: 131.

70. Rouet F, Chaix ML, Inwoley A, Anaky MF, Fassinou P, et al. (2008) Frequent Occurrence of Chronic Hepatitis B Virus Infection among West African HIV Type-1-Infected Children. Hepatitis B in African HIV-1-Co infected Children. Clin Infect Dis 46: 361-366.
71. Chachá SGF, Ferreira SC, Costa TV, Filho LCA, Villanova MG, et al. (2011) Clinical, demographic and epidemiological characteristics of patients with hepatitis B followed at a university hospital in southeastern Brazil predominance of HBeAg negative cases. Rev Socied Brasil Med Trop 44: 13-17.

72. Merrill RM, Hunter BD (2011) Seroprevalence of markers for hepatitis B viral infection. Int J of Infec Dis 15: 78-121.

73. Hadziyannis SJ (2011) Natural history of chronic hepatitis $B$ in Euro-Mediterranean and African countries. J Hepatol 55: 183-191.

74. Schwarz KB, Cloonan YK, Ling SC, Murray KF, Rodriguez-Baez N, et al. (2015) Children with Chronic Hepatitis $\mathrm{B}$ in the United States and Canada. J Pediatr 167: 12871294.

75. Shimakawa Y, Toure-Kane C, MendyM, Thursz M, Lemoine M (2016) Mother-tochildtransmission of hepatitis B in sub-Saharan Africa. Lancet Infect Dis 16: 19-20.

76. Lemoine M, Eholi_ES, Lacombe K (2015) Reducing the neglected burden of viralhepatitis in Africa: strategies for a global approach. J Hepatol 62: 469-476.

77. Keane E, Funk AL, Shimakawa Y (2016) Systematic review with meta-analysis: the risk of mother-to-child transmission of hepatitis $B$ virus infection in sub-Saharan Africa. Aliment Pharmacol Ther 44: 1005-1017.

78. Spearman CW, Afihene M, Ally R, Apica B, Awuku Y, et al. (2017) Hepatitis B in sub-Saharan Africa: strategies to achieve the 2030 elimination targets. Lancet Gastroenterol Hepatol 2: 900-909. 